\title{
ANALISIS ZONASI LAHAN USAHA TAMBANG MENGGUNAKAN METODE $K$-MEANS CLUSTERING BERBASIS SISTEM INFORMASI GEOGRAFI
}

\author{
Analysis of Mining Zonation Using GIS-based Clustering K-means \\ Method
}

\author{
MUHAMMAD LUTFI ${ }^{1,2}$, EMI SUKIYAH ${ }^{2}$ dan NANA SULAKSANA ${ }^{2}$ \\ ${ }^{1}$ Puslitbang Teknologi Mineral dan Batubara \\ Jalan Jenderal Sudirman 623 Bandung 40211 \\ Telp. (022) 6030483, Fax. (022) 6003373 \\ e-mail: muhammadlutfi1961@gmail.com \\ 2 Fakultas Teknik Geologi, Universitas Padjadjaran \\ Jalan Raya Bandung-Sumedang Km.21, Jatinangor
}

\begin{abstract}
ABSTRAK
Pembangunan berbagai sektor perekonomian di Indonesia memanfaatkan setiap ruang yang memberi dampak positif dan negatif. Perencanaan pembangunan Daerah Tingkat II yang disesuaikan dengan karakteristik, potensi dan kebutuhan daerahnya memanfaatkan sumberdaya mineral yang ada secara optimal. Oleh karena itu perlu dibuat suatu zonasi kawasan pertambangan, dengan pendekatan analisis spasial dan mempertimbangkan beberapa parameter agar tidak terjadi tumpang tindih dengan sektor lain. Penentuan zonasi lahan usaha tambang telah banyak dilakukan, di antaranya menggunakan metode statistik K-Means Clustering yang berbasis sistem informasi geografi (SIG). K-Means Clustering adalah metode pengujian pengelompokkan potensi bahan tambang di satu wilayah berdasarkan kriteria keruangan (spasial) yang mengacu kepada karakteristik bukan keruangan (non-spasial). Hasil analisis menunjukkan bahwa zonasi kawasan pertambangan dikelompokkan ke dalam tiga kelompok yaitu kelompok 1 dengan persentase 60,99\%, kelompok 2 sebesar 20,63\% dan kelompok 3 sebesar $16,38 \%$. Metode ini dapat digunakan untuk memilah suatu daerah yang berpotensi bahan tambang untuk dijadikan lahan usaha tambang serta dapat dialokasikan untuk suatu Wilayah Pertambangan (WP).
\end{abstract}

Kata kunci: K-Means clustering, SIG, Zonasi Wilayah Pertambangan.

\begin{abstract}
Development of various economic sectors in Indonesia utilizes every space that can provide positive and negative impacts. Development planning of a Level Two Region in Indonesia is adapted with its characteristics, potency, as well as by optimizing the mineral resources available within the area. Therefore, it is necessary to make a zonation of the mining area by approaching the spatial analysis and considering several parameters to avoid overlapping with other sectors. Zoning determination of a mining business has been carried out using statistical techniques of GIS-based Clustering K-means. The method is the testing system for grouping the potential mining materials in the same area based on spatial criteria by referring to spatial characteristics. The results show that the group of mining areas are divided into Three (3) clusters namely Cluster 1 (60.99\%), Cluster 2 (20.63\%), and Cluster 3 (16.38\%). This method can be used to sort an area that has potential mining material to be used as a mining business to be allocated within a Mining Area (WP).
\end{abstract}

Keywords: K-Means clustering, GIS, Zoning of Mining Areas. 


\section{PENDAHULUAN}

Perkembangan pembangunan sektor perekonomian di berbagai daerah di Indonesia merupakan suatu gambaran kegiatan yang memanfaatkan ruang atau wilayah. Pemanfaatan ruang ini dapat memberikan dampak positif, namun apabila tidak didukung oleh perencanaan yang matang akan mengakibatkan timbulnya berbagai dampak negatif terhadap kondisi ruang atau wilayah itu sendiri, misalnya terjadi pemanfaatan ganda untuk lokasi yang sama.

Kewenangan Pemerintah Daerah dalam perencanaan pembangunan diwujudkan melalui Rencana Pembangunan Lima Tahun Daerah Tingkat II dan Pola Dasar Pembangunan Daerah Tingkat II, sesuai dengan karakteristik, potensi dan kebutuhan daerahnya. Penyusunan Rencana Umum Tata Ruang Wilayah Kabupaten Lebak untuk 2014 dibagi menjadi 2 (dua) kawasan, yaitu Kawasan Budidaya dan Non Budidaya. Sektor Pertambangan Umum yang merupakan bagian dari Kawasan Budidaya kurang mendapat perhatian dalam penyusunan tata ruang wilayah, padahal sektor ini memiliki peran ganda, baik secara sektoral maupun regional (Pemerintah Daerah Kabupaten Lebak Provinsi Banten, 2014).

Secara sektoral, bahan galian industri terkait baik secara langsung ataupun tidak langsung dengan sektor industri, pertanian, perdagangan, peternakan dan lain-lain. Secara regional, bahan galian industri dapat menciptakan peningkatan dan pertumbuhan ekonomi bagi masyarakat dan daerah tersebut (Dani, 2015).

Untuk lebih mengoptimalkan pembangunan dan penataan ruang, aspek pengalokasian zonasi lahan usaha tambang harus mendapatkan perhatian dalam penyusunan Rencana Umum Tata Ruang Daerah. Salah satu upaya untuk mendukung ke arah tercapainya penataan ruang yang serasi dan seimbang adalah dengan mempertimbangkan berbagai aspek, seperti lingkungan, sosial-budaya, kondisi ekonomi dan lain-lain. Langkah ini ditempuh sebagai upaya mengurangi dampak yang akan ditimbulkan oleh keberadaan tambang dalam suatu wilayah.
Langkah yang perlu dilakukan untuk mengantisipasi dampak yang timbul tersebut, salah satunya adalah dengan penetapan zonasi lahan usaha tambang guna mengalokasikan lahan berpotensi bahan tambang sebagai wilayah pertambangan (WP). Hal ini sesuai dengan Undang-Undang No. 4 tahun 2009 (Tunggal, 2012), tentang Pertambangan Mineral dan Batubara yang membawa konsekuensi penting kepada penataan ruang kawasan pertambangan. Pada undang-undang tersebut diamanatkan bahwa kegiatan pertambangan dapat dilaksanakan di areal yang sudah ditetapkan menjadi wilayah pertambangan (WP), dan WP itu sendiri merupakan bagian dari tata ruang nasional.

Penentuan zonasi lahan usaha tambang telah banyak dilakukan. Salah satunya menggunakan metode statistik K-Means Clustering berbasis sistem informasi geografi (SIG). Metode ini digunakan untuk menguji hasil pengelompokkan potensi bahan tambang yang terdapat di satu wilayah berdasarkan kriteria keruangan (spasial) dengan mengacu pada karakteristik bukan keruangan atau non spasial (Suryana, 2011).

Beberapa aspek yang dapat dipertimbangkan dalam melakukan analisis zonasi lahan usaha tambang meliputi :

- lokasi sebaran potensi bahan galian industri yang terdiri dari luas, cadangan dan kualitas;

- lokasi sebaran potensi bahan galian bukan logam dan batuan;

- geologi, topografi, hidrologi, gerakan tanah, kebencanaan, irigasi, kedalaman efektif tanah, sarana dan prasarana;

- sosial-ekonomi, antara lain kependudukan, tenaga kerja, tingkat pendidikan, potensi desa, pasar, pendapatan dan lain-lain;

- lingkungan berupa identifikasi dan analisis dampak negatif terhadap lingkungan sekitarnya;

- kebijaksanaan yang berkaitan dengan usaha pertambangan di Kabupaten Lebak (Dani, 2015).

Hasil analisis merupakan area potensi yang secara spasial dan non spasial mempunyai potensi bahan tambang yang layak untuk dijadikan lahan usaha pertambangan. Selanjutnya diharapkan dapat menjadi masukan bagi daerah dalam menyusun 
kebijakan mengenai penetapan wilayah pertambangan.

Dalam penentuan analisis zonasi lahan usaha tambang, ada beberapa pengertian yang digunakan, di antaranya :

1. Aspek fisik adalah informasi potensi dan permasalahan fisik yang ada di suatu daerah, seperti geologi, bentang alam, kemampuan lahan, penggunaan lahan, kawasan, dan sebagainya. Berdasarkan sumbernya, aspek ini merupakan data spasial;

2. Aspek nonfisik adalah informasi sosioekonomi dan budaya serta kebijaksanaan yang ada di suatu daerah. Berdasarkan sumbernya, aspek ini merupakan data non spasial;

3. Bahan galian industri adalah semua jenis bahan galian non logam yang bersifat ruah, serta terbentuknya di alam menyebar secara lateral dan dekat dengan permukaan;

4. Data non spasial adalah data yang berbentuk tekstual, numerik, ataupun deskripsi seperti kalimat dan tabel;

5. Data spasial adalah data yang berbentuk gambar ataupun grafis, seperti peta, grafik dan foto;

6. Kawasan adalah wilayah yang batas dan sistemnya ditentukan oleh aspek fungsional, yaitu kawasan lindung dan budi daya

7. Kawasan budi daya adalah kawasan yang dapat dimanfaatkan dengan memperhatikan asas konservasi;

8. Kawasan lindung adalah kawasan yang memiliki karakteristik unik, sehingga memerlukan pengelolaan atau perlindungan khusus dalam pengembangannya. Kawasan lindung hanya dapat dimanfaatkan untuk konservasi, rehabilitasi, penelitian, wisata lingkungan, dan kegiatan lain yang sejenis;

9. Penggunaan lahan adalah gambaran penggunaan lahan atau tutupan lahan secara aktual, dan pada umumnya dinyatakan dengan satuan luas (kondisi nyata bukan rencana);

10. Rencana Tata Ruang Wilayah (RTRW) adalah rencana penetapan atau alokasi lahan untuk berbagai sektor ekonomi dalam rangka pemanfaatan sumber daya alam yang terkandung di dalamnya secara optimum, terencana, dan berkesinambungan;

11. SIG adalah teknologi sistem pengolahan data yang mempunyai kemampuan analisis, pemodelan, dan penyajian data, baik tekstual (data spasial) maupun grafis (data non spasial) yang semuanya mengacu pada lokasi di muka bumi;

12. Wilayah adalah ruang yang berupa kesatuan geografis beserta segenap unsur terkait terhadapnya yang batas dan sistemnya ditentukan berdasarkan aspek administratif dan/atau aspek fungsional;

13. Zonasi adalah alokasi lahan yang wujud struktural dan pola pemanfaatannya disusun sesuai dengan kondisi fisik dan nonfisik sumber daya alam dan lingkungan di dalamnya;

14. Zona Pertambangan adalah lokasi lahan potensi bahan galian (Suryana $d k k$., 2005);

15. Zonasi Wilayah Pertambangan adalah pengalokasian lahan potensi bahan galian dengan mempertimbangkan kondisi lingkungan dan peraturan yang berlaku (Tim Asistensi Perencanaan Terpadu dan Terkendali, 1987).

\section{METODE}

Metode yang digunakan dalam analisis penentuan zonasi lahan usaha tambang berbasis Sistem Informasi Geografi (SIG) terdiri dari (Gambar 1):

$\checkmark$ Pengumpulan data berupa data sekunder yang diperoleh dari hasil inventarisasi potensi bahan tambang di Kabupaten Lebak, Provinsi Banten;

$\checkmark$ Pengolahan data dilakukan dengan membuat field (nama kolom) pada masing-masing data ke dalam format sistem informasi geografi (SIG), dengan tujuan untuk memudahkan pengelompokkan pada analisis;

$\checkmark$ Analisis data dilakukan melalui dua tahapan yakni analisis spasial dan non spasial. 


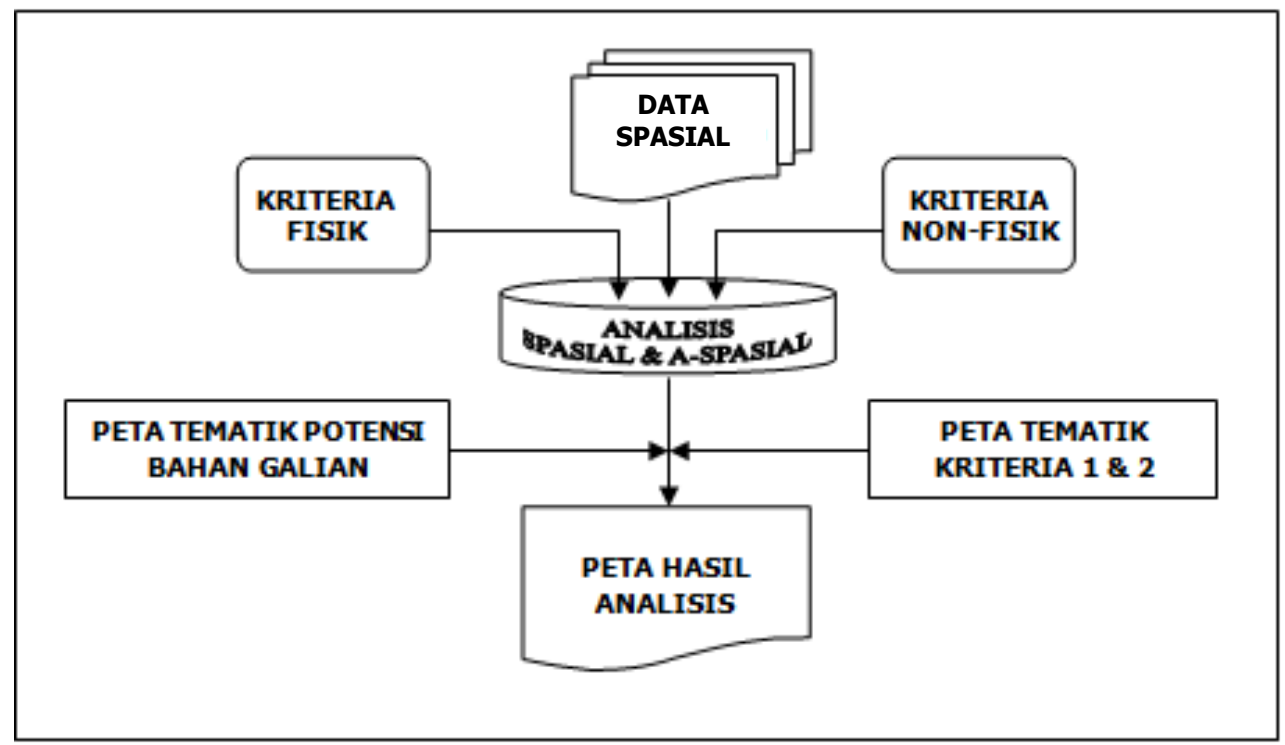

Gambar 1. Proses analisis dalam menentukan zonasi lahan usaha tambang (Antono $d k k ., 2009$ ).

\section{Analisis Spasial}

Pada proses spasial digunakan metode tumpang susun peta yang dilakukan dengan menumpukan peta potensi bahan tambang pada peta tematik yang dijadikan sebagai kriteria dalam memanfaatkan teknologi SIG.

Pengelolaan data menggunakan perangkat lunak Maplnfo dilakukan dengan teknik erase (penghapusan), buffering (penyanggaan) dan splitting (pemisahan). Metode ini menerapkan teknik analisis spasial sederhana berupa ekspresi logika dengan operator : and, or, dan Xor (Pitney Bowes Software Inc., 2006).

Analisis spasial dilakukan dengan metode tumpang susun (overlay) yang sangat efektif dan umum ditemukan pada perangkat lunak SIG. Penerapan operasi menggunakan boolean dilakukan pada tahap analisis dengan cara tumpang susun terhadap peta dasar (drived layers) kemudian diuji untuk setiap drived layers dan interpreted layers. Dengan menetapkan berbagai kriteria seperti di atas maka penerapan harus mengikuti peraturan yang telah ditetapkan baik oleh pemerintah pusat maupun daerah, seperti luas potensi bahan tambang yang benar-benar bebas dari terjadinya pergesekan kepentingan pada operasional penggunaan lahan.

Langkah selanjutnya untuk lahan potensi bahan tambang terpilih berdasarkan analisis spasial, dilakukan pembobotan khususnya bagi hasil proses splitting (pemisahan) untuk mengetahui keterkaitan potensi bahan tambang yang terpilih dengan peta tematik yang dijadikan kriteria.

\section{Analisis Non Spasial}

Ada tiga (3) cara yang dapat dilakukan untuk menganalisisnya, yaitu :

a) Teknik pengelompokkan (cluster).

Pada umumnya terdapat dua teknik pengelompokkan, yaitu metode hierarchical dan non-hierarchical (Hair dkk., 1998).

- Hierarchical method

Proses pada metode hierarki dilakukan secara bertingkat. Metode ini dimulai dengan mengelompokan dua atau lebih suatu obyek yang mempunyai kesamaan paling dekat. Kemudian proses diteruskan ke obyek yang lain yang memiliki kedekatan kedua. Demikian seterusnya sehingga setiap kelompok akan membentuk semacam pohon dengan hierarki (tingkatan) yang jelas antar obyek mulai dari yang paling mirip sampai ke yang tidak mirip, hingga membentuk suatu kelompok. Metode ini digunakan untuk menentukan banyaknya gugus yang diinginkan.

- Non-Hierarchical method (K-Means Clustering) 
Metode ini lebih dikenal dengan istilah K-Means Clustering (Hilda, 2009). Pada metode ini, pengelompokan dilakukan berdasarkan jarak terkecil antara obyek dengan pusat gugus

b) Penentuan kriteria

Pada penelitian ini digunakan delapan variabel penimbang untuk pengelompokan lahan usaha tambang, yaitu nilai bahan tambang, volume cadangan, kedalaman efektif tanah, kemiringan, ketinggian, kebencanaan, penggunaan tanah, dan jarak. Jenis data pada penelitian ini memiliki skala pengukuran ordinal dan rasio (Tabel 1 ).

c. Tahapan penelitian

Tahapan yang harus dilakukan untuk menentukan pengelompokan zonasi lahan usaha tambang meliputi:
- Transformasi Data. Pada K-Means Clustering diperlukan skala pengukuran minimal dari interval, meskipun ada beberapa variabel yang memiliki skala pengukuran ordinal. Oleh karena itu, perlu dilakukan transformasi data sebelum dianalisis menggunakan method of successive interval (Al Rasyid, 1993), dengan langkah sebagai berikut:

- memperhatikan frekuensi perolehan skor berdasarkan obyek penelitian untuk setiap variabel;

- penggunaan frekuensi dibagi dengan banyaknya obyek penelitian dan hasilnya disebut proporsi;

- penentuan proporsi kumulatif;

- penggunaan tabel distribusi normal untuk menghitung nilai $z$ pada setiap proporsi kumulatif yang diperoleh;

Tabel 1. Kriteria skala pembobotan (Suryana, 2011)

\begin{tabular}{|c|c|c|c|c|}
\hline No. & Variabel & Kriteria & Bobot & Keterangan \\
\hline \multirow{6}{*}{1} & \multirow{6}{*}{$\begin{array}{l}\text { Nilai bahan } \\
\text { tambang }\end{array}$} & Sirtu & 1 & \multirow{6}{*}{$\begin{array}{l}\text { Skor didasarkan kepada nilai manfaat bahan tambang di } \\
\text { Kabupaten Lebak. Semakin tinggi nilai skor, semakin tinggi } \\
\text { nilai bahan tambang. }\end{array}$} \\
\hline & & Pasir & 2 & \\
\hline & & Batugamping & 3 & \\
\hline & & Batubelah & 4 & \\
\hline & & Pasir kuarsa & 5 & \\
\hline & & Tanah liat & 6 & \\
\hline 2 & $\begin{array}{l}\text { Luas sebaran } \\
\text { potensi } \\
\text { cadangan }\end{array}$ & $\begin{array}{l}\text { Luas sebaran } \\
\text { potensi cadangan }\end{array}$ & 1 & $\begin{array}{l}\text { Diambil dari data cadangan yang mempunyai IUP } 50 \text { hektar } \\
\text { ke atas dengan klasifikasi cadangan hipotetik }\end{array}$ \\
\hline \multirow{4}{*}{3} & \multirow{4}{*}{$\begin{array}{l}\text { Kedalaman } \\
\text { efektif tanah }\end{array}$} & $>90 \mathrm{~cm}$ & 1 & \multirow{4}{*}{$\begin{array}{l}\text { Skor berdasarkan tingkat kemudahan dalam menambang. } \\
\text { Semakin tinggi nilai skor, semakin mudah dalam } \\
\text { menambang. }\end{array}$} \\
\hline & & $60-90 \mathrm{~cm}$ & 2 & \\
\hline & & $30-60 \mathrm{~cm}$ & 3 & \\
\hline & & $<30 \mathrm{~cm}$ & 4 & \\
\hline \multirow{5}{*}{4} & \multirow{5}{*}{$\begin{array}{l}\text { Kemiringan } \\
\text { lereng }\end{array}$} & $>40 \%$ & 1 & \multirow{5}{*}{$\begin{array}{l}\text { Skor berdasarkan tingkat keamanan dalam menambang } \\
\text { (kestabilan lereng). Semakin tinggi skor, semakin aman } \\
\text { ditambang. SK Menteri Pertanian No: 683/Kpts/Um/8/1981. }\end{array}$} \\
\hline & & $25-40 \%$ & 2 & \\
\hline & & $15-25 \%$ & 3 & \\
\hline & & $8-15 \%$ & 4 & \\
\hline & & $0-8 \%$ & 5 & \\
\hline \multirow{3}{*}{5} & \multirow{3}{*}{ Ketinggian } & $500-1000 m \mathrm{dpl}$ & 1 & \multirow{3}{*}{$\begin{array}{l}\text { Skor berdasarkan tingkat kemudahan dalam menambang. } \\
\text { Peraturan Menteri PU No. 41/PRT/M/2007. }\end{array}$} \\
\hline & & $100-500 \mathrm{~m} \mathrm{dpl}$ & 2 & \\
\hline & & $25-100 \mathrm{~m} \mathrm{dpl}$ & 3 & \\
\hline \multirow{3}{*}{6} & \multirow{3}{*}{$\begin{array}{l}\text { Rawan } \\
\text { bencana }\end{array}$} & Tinggi & 1 & \multirow{3}{*}{$\begin{array}{l}\text { Skor berdasarkan tingkat resiko terjadinya bencana } \\
\text { Permen PU No. 22/PRT/M/2007. }\end{array}$} \\
\hline & & Sedang & 2 & \\
\hline & & Rendah & 3 & \\
\hline \multirow{3}{*}{7} & \multirow{3}{*}{$\begin{array}{l}\text { Pemanfaatan } \\
\text { tanah }\end{array}$} & Sawah & 1 & \multirow{3}{*}{$\begin{array}{l}\text { Skor berdasarkan tingkat kepentingan penggunaan lahan. } \\
\text { Semakin tinggi nilai skor, semakin baik digunakan. }\end{array}$} \\
\hline & & Perkebunan & 2 & \\
\hline & & Tegalan & 3 & \\
\hline 8 & Jarak & $\begin{array}{c}>2 \mathrm{~km} \\
1-2 \mathrm{~km} \\
0.5-1 \mathrm{~km} \\
0-0.5 \mathrm{~km}\end{array}$ & 1 & $\begin{array}{l}\text { Skor berdasarkan kedekatan jarak lokasi diukur dari jalan. } \\
\text { Tidak dilakukan pembedaan antara jenis jalan. Semakin } \\
\text { tinggi skor, semakin dekat dengan sarana jalan. }\end{array}$ \\
\hline
\end{tabular}


- nilai densitas setiap nilai z ditentukan menggunakan tabel densitas.

Rumus fungsi densitas:

$$
f(z)=\frac{1}{\sqrt{2 \pi}} e^{-\frac{1}{2} z^{2}}
$$

dengan $\pi=3,14$

- nilai skala ditentukan dengan rumus:

$$
N S=\frac{(D K S)-(D K)}{(P K S)-(P K K S)}
$$

$$
\begin{aligned}
& \mathrm{DK}=\text { densitas kelas } \\
& \text { DKS = densitas kelas sebelumnya } \\
& \text { PKK = proporsi kumulatif kelas } \\
& \text { PKKS }=\text { proporsi komulatif kelas } \\
& \text { sebelumnya } \\
& \text { - nilai transformasi ditentukan } \\
& \text { menggunakan rumus }
\end{aligned}
$$

$\mathrm{Y}=\mathrm{NS}+\left[1+\left|N S_{\min }\right|\right]$

Software Excel digunakan untuk operasi transformasi data ordinal menjadi interval;

- Standardisasi Data. Standardisasi data digunakan untuk mengurangi variasi data antar variabel. Karena setiap variabel memiliki satuan yang berbeda (sangat bervariasi dalam satuan), maka sebelum dilakukan analisis, dilakukan standardisasi data menggunakan rumus:

$Z_{i j}=\frac{X_{i j}-\bar{X}_{j}}{S_{j}}$

xij merupakan nilai dari data ke-i dan variabel ke-j. $j x$ dan $S j$ merupakan ratarata dan standar deviasi variabel ke- $j$, untuk $i=1,2, \ldots, 80$ dan $j=1,2, \ldots, 8$.

- Jumlah kelompok atau gugus. Dalam menentukan banyak gugus yang akan terbentuk, digunakan statistik pseudo-F dengan rumus :

pseudo- $\mathrm{F}=\frac{\mathrm{tr} / \mathbf{B} /(\mathrm{K}-1)]}{\operatorname{tr} / \mathbf{W} /(\mathrm{n}-\mathrm{K})]}$

B adalah matriks jumlah kuadrat antar gugus, $W$ adalah matriks jumlah kuadrat di dalam gugus, $\mathrm{K}$ adalah banyaknya gugus, dan $\mathrm{n}$ adalah banyaknya obyek, yang dapat dinyatakan sebagai berikut :

$$
\mathrm{B}=\sum_{\mathrm{k}=1}^{\mathrm{K}} \sum_{\mathrm{j}=1}^{\mathrm{j}} \mathrm{n}_{\mathrm{k}}\left(\overline{\mathrm{X}}_{\mathrm{jk}} \overline{\mathrm{X}}_{\mathrm{j}}\right)\left(\overline{\mathrm{X}}_{\mathrm{jk}} \overline{\mathrm{X}}_{\mathrm{j}}\right)^{\prime}
$$

$\mathrm{W}=\sum_{\mathrm{k}=1}^{\mathrm{K}} \sum_{\mathrm{j}=1}^{\mathrm{J}} \sum_{\mathrm{i}=1}^{\mathrm{n}_{\mathrm{k}}}\left(\mathrm{X}_{\mathrm{ijk}}-\overline{\mathrm{X}}_{\mathrm{jk}}\right)\left(\mathrm{X}_{\mathrm{ijk}}-\overline{\mathrm{X}}_{\mathrm{jk}}\right)^{\prime}(5)$

dengan: $\quad k=1,2, \ldots, K \quad$ menunjukkan banyak gugus, $j=1,2, \ldots, J$ menunjukkan banyaknya variabel, $\quad i=1,2, \ldots, n k$ menunjukkan banyaknya obyek pada gugus- $k$.

Semakin besar nilai pseudo-F maka semakin baik hasil pengelompokkan yang dimiliki atau dapat diartikan pula bahwa pemilihan $k$ sebagai solusi terbaik ditunjukkan oleh nilai pseudo-F yang terbesar dari beberapa solusi $k$ gugus yang dilakukan (Lattin, Carroll dan Green, 2003). Penentuan jumlah gugus bisa juga berdasarkan penilaian peneliti dengan berbagai pertimbangan. Pengelompokkan ini dinamakan dengan K-Means Clustering.

- Pengelompokan K-Means Clustering. Dalam menentukan pengelompokan dengan K-Means Clustering digunakan algoritma sebagai berikut :

Langkah 1: Menentukan banyak klaster (k), kemudian pilih k observasi sebagai pusat gugus;

Langkah 2: Menghitung jarak dari masing-masing obyek ke pusat k gugusnya, menggunakan persamaan Euclidean Distance. Secara umum, Euclidean Distance antara obyek $i$ dan $j$ dirumuskan sebagai berikut:

$\mathrm{d}_{\mathrm{ij}=}\left(\sum_{\mathrm{i}=0}^{\mathrm{n}}\left(\mathrm{X}_{\mathrm{ik}}-\mathrm{X}_{\mathrm{jk}}\right)^{2}\right)^{1 / 2}$

$\mathrm{k}=1,2, \ldots$,

$p$ menunjukkan banyaknya variabel.

Semakin kecil jarak Euclidean Distance, semakin mirip obyek-obyek tersebut dan sebaliknya;

Langkah 3: Kelompokkan obyek ke-i ke pusat gugus yang terdekat. Hitung kembali pusat dari gugus yang menerima obyek baru dan yang kehilangan obyek. 
Langkah 4: Apabila di langkah ke-3 keanggotaan gugus tidak berubah, maka proses telah konvergen. Jika satu keanggotaan gugus pada akhir proses masih berubah, maka ulangi kembali langkah ke-2 dengan partisi baru sampai keanggotaan gugus tidak berubah.

- Interpretasi Gugus. Pemberian nama gugus berdasarkan hasil interpretasi gugus, pemberian nama untuk gugus yang terbentuk didasarkan pada gambaran karakteristik masing-masing klaster tersebut. Hal ini dilakukan untuk lebih menjelaskan perbedaan antar gugus yang terbentuk. Untuk menginterpretasi gugus dan membuat profil, gunakan rata-rata setiap gugus pada setiap variabel (cluster's centroid). Karena dalam analisis gugus menggunakan data yang telah distandardisasi, maka dalam menginterpretasikan karakteristik gugus sebaiknya menggunakan nilai rata-rata (cluster's centroid) dari data yang telah dikembalikan ke dalam bentuk semula.

- Validasi Gugus. Validasi gugus dilakukan guna mengecek hasil pengelompokkan yang telah dihasilkan. Langkah yang harus dilakukan untuk mengetahui keakuratan gugus, di antaranya:

a. membagi data menjadi dua bagian (bagian I dan II).

b. menghitung cluster's centroid untuk data bagian I menggunakan $K$ Means Clustering.

c. gunakan cluster's centroid data bagian I sebagai pusat gugus awal untuk proses K-Means Clustering pada data bagian II.

d. Membandingkan hasil pengelompokkan pada bagian (c) dengan hasil pengelompokkan pada data asli. Hasil pengelompokkaan dikatakan sahih apabila hasil pengelompokkan pada data validasi bagian II tadi tidak jauh berbeda dengan pengelompokkan pada data asli.

\section{HASIL DAN PEMBAHASAN}

\section{Analisis Spasial}

Hasil analisis menunjukkan bahwa dari 28 kecamatan (340 desa) di Kabupaten Lebak, diperoleh 2307 lahan usaha tambang untuk bahan tambang industri yang telah memenuhi kriteria zonasi lahan usaha tambang. Hasil analisis diperlihatkan pada Gambar 2.

\section{Penentuan Banyak Gugus}

Untuk menentukan banyak gugus yang optimal dapat dilihat dari nilai pseudo- $F$ menggunakan Persamaan (3). Berikut ini adalah nilai pseudo- $F$ beberapa solusi gugus yang terbentuk. Banyak gugus terbaik ditunjukkan oleh nilai pseudo- $F$ yang terbesar dari beberapa solusi k gugus yang dilakukan. Berdasarkan hasil perhitungan, dapat dilihat bahwa nilai pseudo- $F$ untuk 3 gugus menunjukkan nilai yang paling maksimum di antara banyak gugus lainnya. Dengan demikian, banyak gugus yang optimal digunakan dalam analisis $K$ means Clustering ini adalah 3 gugus.

Pembentukan gugus pertama pada K-Means Cluster dengan menggunakan bantuan software SPSS 17, diperoleh output pada Tabel 2.

Tabel 2. Initial cluster centers

\begin{tabular}{lrrr}
\hline & \multicolumn{3}{c}{ Cluster } \\
\cline { 2 - 4 } & \multicolumn{1}{c}{1} & \multicolumn{1}{c}{2} & \multicolumn{1}{c}{3} \\
\hline Zscore(skor_jnsba) & -1.43237 & 1.04723 & .22069 \\
Zscore(skor_ketin) & 2.21310 & .35177 & -3.37088 \\
Zscore(skor_kemir) & -.66507 & 1.70270 & -.66507 \\
Zscore(skor_pengl) & -1.49988 & 2.45241 & .47626 \\
Zscore(skor_erosi) & -.38357 & 2.60595 & -.38357 \\
Zscore(skor_air) & -.61521 & -.61521 & -1.50561 \\
Zscore(skor_crhhj) & -.71452 & 1.50256 & -.71452 \\
Zscore(skor_rutr) & 1.19256 & .13358 & -.92540 \\
\hline
\end{tabular}

Tabel initial cluster di atas menunjukkan tiga buah gugus yang pertama kali terbentuk. Kemudian metode K-Means Cluster akan menguji dan melakukan realokasi gugus yang ada. Proses tersebut dinamakan Iteration, yang memuat perubahan pada initial cluster dapat dilihat pada Tabel 3. 


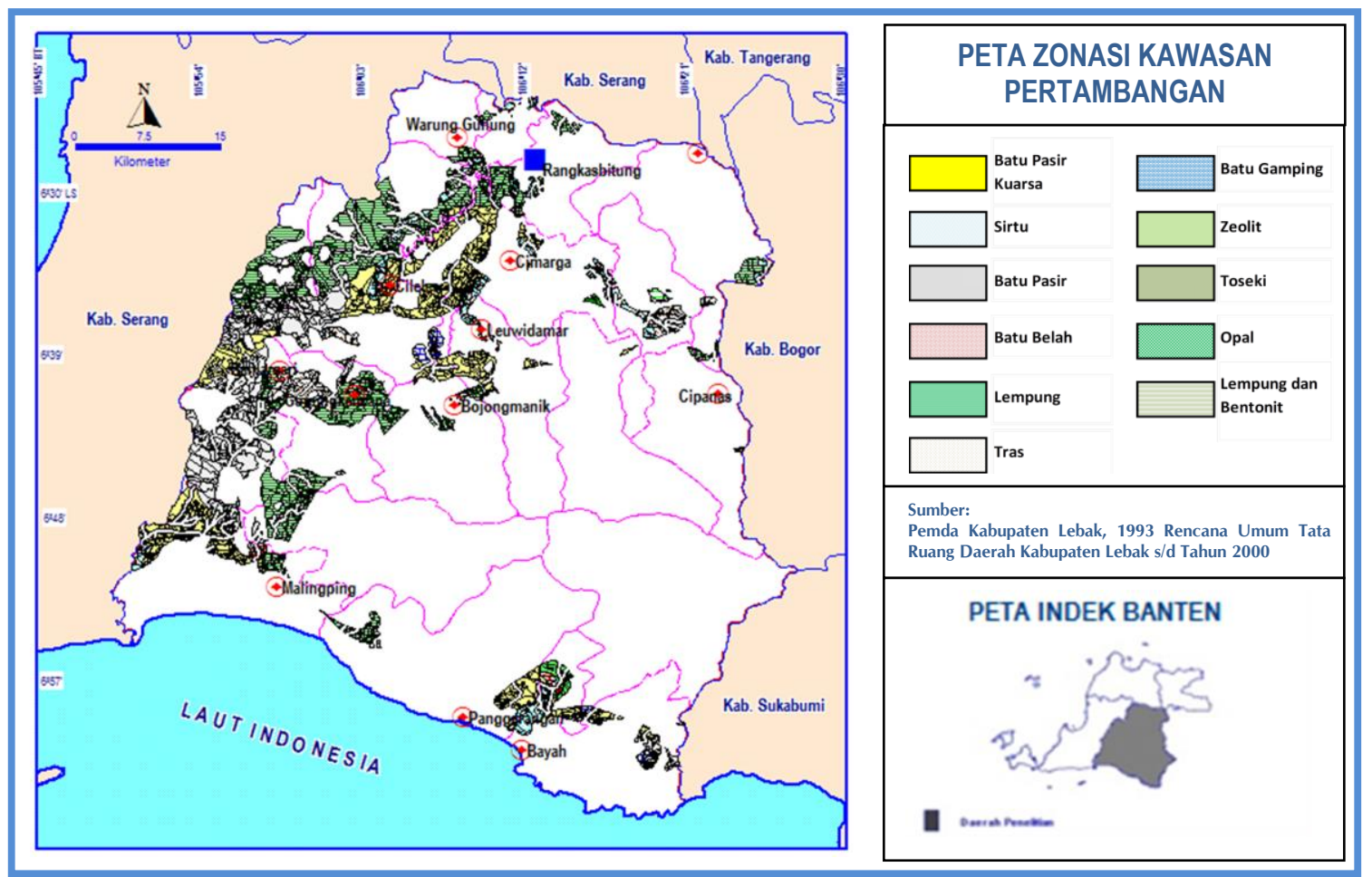

Gambar 2. Peta zonasi kawasan pertambangan

Tabel 3. Iteration history ${ }^{a}$

\begin{tabular}{cccc}
\hline \multirow{2}{*}{ Iteration } & \multicolumn{3}{c}{ Change in Cluster Centers } \\
\cline { 2 - 4 } & 1 & 2 & 3 \\
\hline 1 & 2.880 & 2.768 & 2.461 \\
2 & .135 & .362 & .181 \\
3 & .074 & .209 & .045 \\
4 & .044 & .090 & .065 \\
5 & .052 & .039 & .169 \\
6 & .015 & .017 & .051 \\
7 & .000 & .000 & .000 \\
\hline
\end{tabular}

Hasil dari K-Means adalah Final Cluster Centers, yang berisi tiga klaster untuk membagi 2307 zonasi kawasan pertambangan berdasarkan jenis batuan, ketinggian, kemiringan, penggunaan lahan, kepekaan terhadap erosi, air tanah permukaan, curah hujan, pola rencana tata ruang. Analisis Pengelompokan zonasi kawasan pertambangan berdasarkan jenis batuan, ketinggian, kemiringan, penggunaan lahan, kepekaan terhadap erosi, air tanah permukaan, curah hujan, pola rencana tata ruang.

\section{Analisis Pengelompokan Zonasi Kawasan Pertambangan Berdasarkan Delapan Variabel}

Dari delapan variabel yang relevan, untuk membedakan isi gugus, dapat dianalisis zonasi kawasan pertambangan yang termasuk Gugus 1, 2, dan 3. Pengelompokkan 2307 lahan pertambangan ditampilkan pada Tabel 4, Gambar 3, 4 dan 5. 
Tabel 4. Hasil pengelompokkan zonasi kawasan pertambangan

\begin{tabular}{|c|c|c|c|c|}
\hline \multirow{2}{*}{ Gugus } & \multirow{2}{*}{ Jumlah } & \multirow{2}{*}{ Persentase } & \multicolumn{2}{|c|}{ Anggota } \\
\hline & & & Bahan Galian & Kecamatan \\
\hline \multirow{10}{*}{1} & \multirow{10}{*}{1407} & \multirow{10}{*}{60,99} & Batupasir & Cijaku \\
\hline & & & Tras & Cikulur \\
\hline & & & Batupasir kuarsa & Cileles \\
\hline & & & Lempung & Cimarga \\
\hline & & & Batubelah & Gunungkancang \\
\hline & & & Sirtu & Cipanas \\
\hline & & & Batugamping & Leuwidamar \\
\hline & & & Opal & Maja \\
\hline & & & Toseki & Malingping \\
\hline & & & Lempung dan Bentonit & Muncang \\
\hline \multirow{5}{*}{2} & \multirow{5}{*}{476} & \multirow{5}{*}{20,63} & Sirtu & Cikulur \\
\hline & & & Lempung & Cileles \\
\hline & & & Batupasir kuarsa & Cimarga \\
\hline & & & Lempung dan bentonit & Maja \\
\hline & & & Opal & Malingping \\
\hline \multirow{7}{*}{3} & \multirow{7}{*}{424} & \multirow{7}{*}{18,38} & Tras & Cibadak \\
\hline & & & Batugamping & Cibeber \\
\hline & & & Batupasir kuarsa & Cijaku \\
\hline & & & Zeolit & Cikulur \\
\hline & & & Batubelah & Cileles \\
\hline & & & Sirtu & Cipanas \\
\hline & & & Lempung & Gunungkancang \\
\hline
\end{tabular}

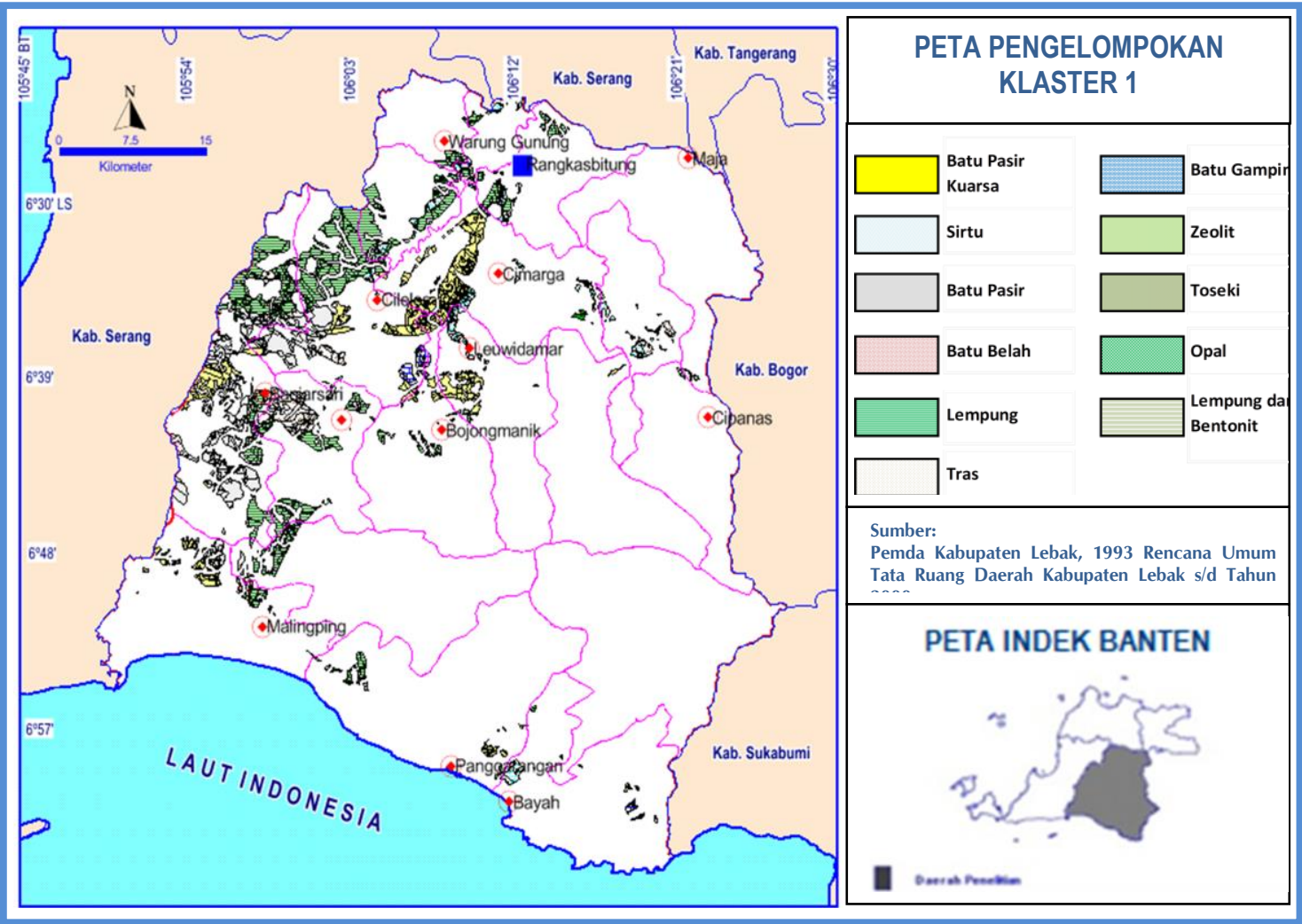

Gambar 3. Peta pengelompokan Gugus 1 


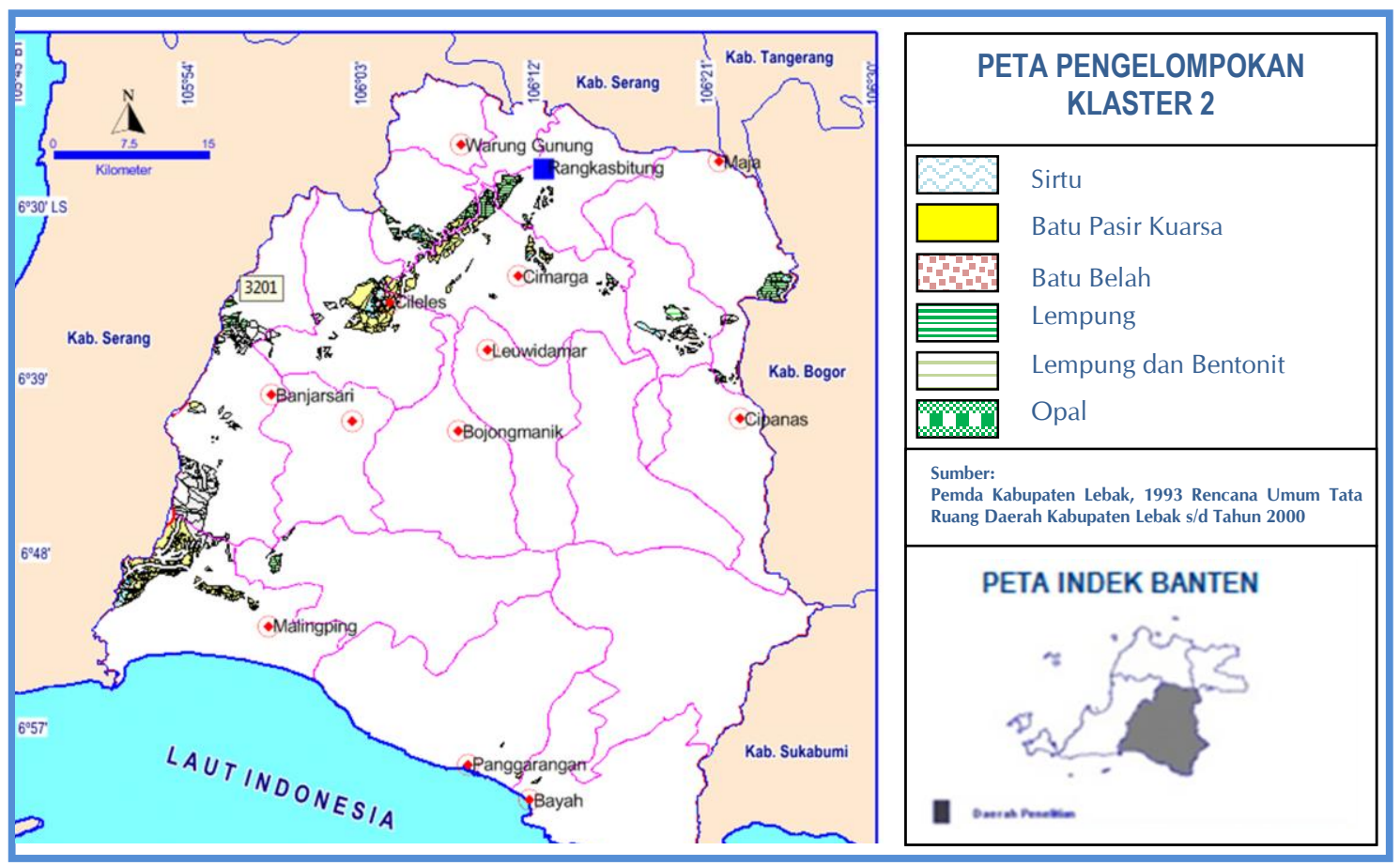

Gambar 4. Peta pengelompokan Gugus 2

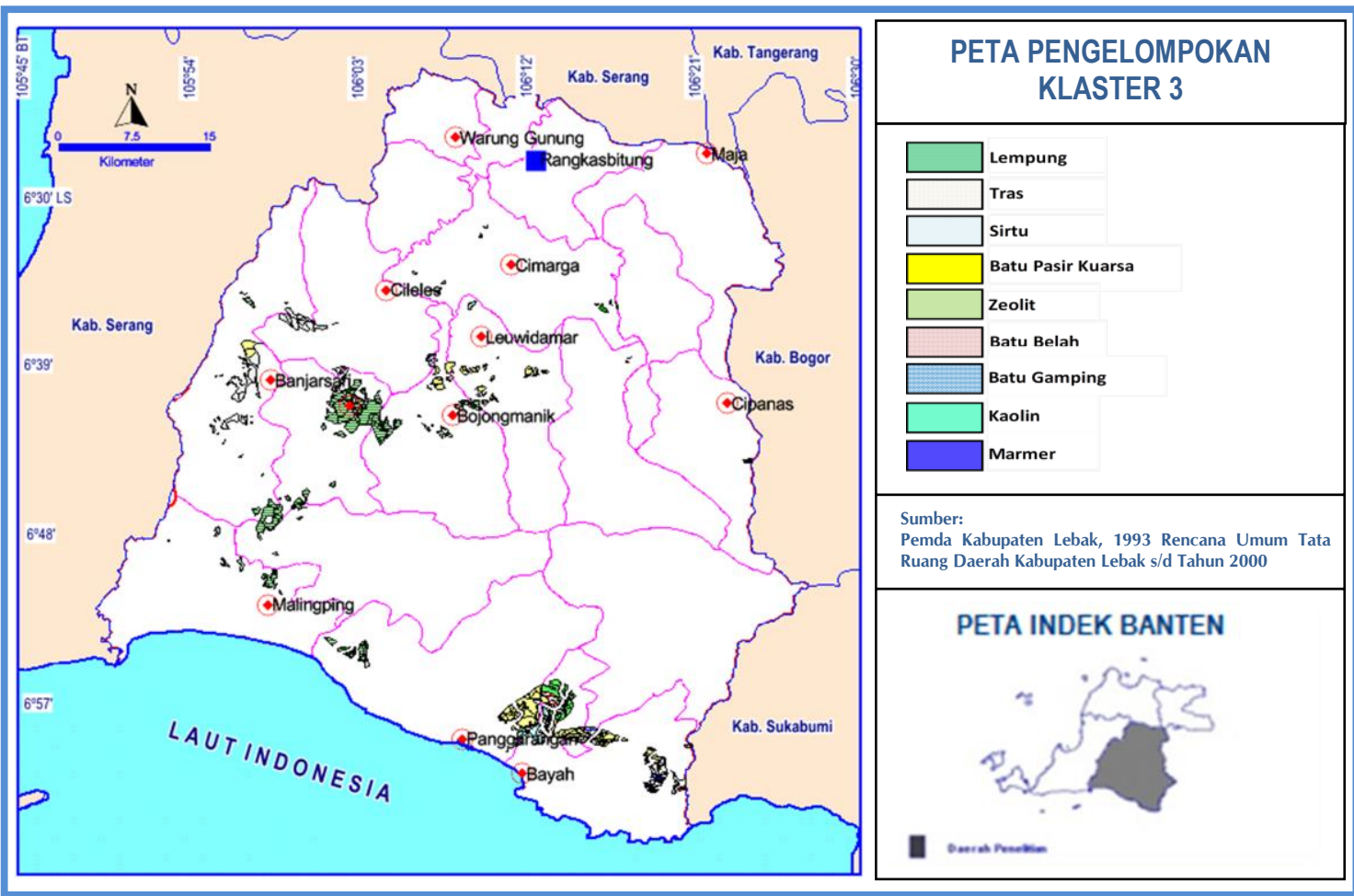

Gambar 5. Peta pengelompokan Gugus 3 


\section{Interpretasi Karakteristik Klasifikasi Zonasi Kawasan Pertambangan}

Interpretasi terhadap ketiga gugus yang terbentuk dimulai dengan menganalisis variable-variabel yang membedakan ke tiga gugus tersebut. Analisis ini dilakukan dengan melihat nilai signifikansi tabel ANOVA. Apabila nilai signifikansi $>0,05$, maka tidak ada perbedaan yang berarti antara Gugus 1, 2 dan 3 dan sebaliknya jika nilai signifikansi $<$ 0,05 maka ada perbedaan yang berarti antara Gugus 1, 2 dan 3 yang berhubungan dengan variabel tersebut. Tabel 5 menyajikan variabel-variabel pembeda kedua segmen.

Berdasarkan Tabel 5, terlihat bahwa angka signifikan untuk semua variabel yaitu jenis batuan, ketinggian, kemiringan, penggunaan lahan, kepekaan terhadap erosi, air tanah permukaan, curah hujan, pola rencana tata ruang lebih kecil dari 0,05. Hal ini menunjukkan bahwa ada perbedaan yang berarti antara Gugus 1, 2, dan 3 yang berhubungan dengan semua variabel tersebut.
Sebagai pedoman, semakin besar angka $F$, semakin besar perbedaan antara Gugus 1, 2 dan 3 untuk variabel yang bersangkutan. Berdasarkan tabel ANOVA di atas, terlihat angka $F$ terbesar adalah 2.333,920. Hal ini menunjukkan zonasi kawasan pertambangan dalam Gugus 1, variabel ketinggian sangat berpengaruh bila dibandingkan dengan hal sama pada Gugus 2, dan 3.

Setelah diketahui variabel-variabel yang relevan untuk membedakan Gugus 1, 2, dan 3 selanjutnya dianalisis variabel masingmasing zonasi kawasan pertambangan yang termasuk ke dalam masing-masing gugus yang dapat dilihat dari nilai akhir pusat gugus dari variabel berbeda (Tabel 6).

Berdasarkan tabel final cluster center di atas dapat disimpulkan bahwa terdapat delapan variabel yang relevan untuk membedakan isi gugus dalam mengelompokkan zonasi kawasan pertambangan yang termasuk Gugus 1, 2 dan 3.

Tabel 5. Anova uji keberartian variabel pembeda gugus

\begin{tabular}{lccccrc}
\hline & \multicolumn{2}{c}{ Cluster } & \multicolumn{2}{c}{ Error } & \multirow{2}{*}{$\mathrm{F}$} & \multirow{2}{*}{ Sig. } \\
\cline { 2 - 5 } & Mean Square & df & Mean Square & df & & .000 \\
Zscore(skor_jnsba) & 59.105 & 2 & .950 & 2304 & 62.245 & .000 \\
Zscore(skor_ketin) & 771.965 & 2 & .331 & 2304 & 2333.920 & .000 \\
Zscore(skor_kemir) & 268.027 & 2 & .768 & 2304 & 348.900 & .000 \\
Zscore(skor_pengl) & 16.894 & 2 & .986 & 2304 & 17.131 & .000 \\
Zscore(skor_erosi) & 652.815 & 2 & .434 & 2304 & 1503.531 & .000 \\
Zscore(skor_air) & 41.476 & 2 & .965 & 2304 & 42.986 & .000 \\
Zscore(skor_crhhj) & 268.056 & 2 & .768 & 2304 & 348.949 & .000 \\
Zscore(skor_rutr) & 140.483 & 2 & .879 & 2304 & 159.835 & \\
\hline
\end{tabular}

Tabel 6. Nilai pusat gugus

\begin{tabular}{lccc}
\hline & \multicolumn{3}{c}{ Gugus } \\
\cline { 2 - 4 } & 1 & 2 & 3 \\
\hline Zscore(skor_jnsba) & -.13706 & .43775 & -.03662 \\
Zscore(skor_ketin) & .42189 & .28530 & -1.72027 \\
Zscore(skor_kemir) & -.14956 & .90515 & -.51988 \\
Zscore(skor_pengl) & -.09678 & .14829 & .15467 \\
Zscore(skor_erosi) & -.38357 & 1.47546 & -.38357 \\
Zscore(skor_air) & .12014 & -.36268 & .00849 \\
Zscore(skor_crhhj) & -.22683 & .94363 & -.30666 \\
Zscore(skor_rutr) & -.08394 & .63414 & -.43338 \\
\hline
\end{tabular}


Gugus pertama yaitu kelompok zonasi kawasan pertambangan dengan karakteristik memiliki nilai ketinggian lebih tinggi di dibandingkan dengan gugus lainnya. Bahan galian pada gugus ini boleh ada penambangan dengan persyaratan untuk diambil karena berada pada ketinggian dan air permukaan yang rendah.

Gugus kedua merupakan zonasi kawasan pertambangan dengan karakteristik memiliki tingkat kepekaan erosi yang rendah, intensitas curah hujan yang rendah dan tingkat kemiringan yang cukup aman, peruntukan RUTR (Rencana Umum Tata Ruang) berada pada kawasan non budidaya sehingga memudahkan untuk pengambilan bahan galian. Pada gugus ini diperbolehkan adanya penambangan.

Gugus ketiga merupakan zonasi kawasan pertambangan terletak pada penggunaan lahan tegalan tetapi faktor lainnya seperti ketinggian berada pada 1500 - 2000 mdpl sehingga untuk pengambilan bahan galian agak sulit, karena itu pada gugus ini boleh ditambang hingga perijinan habis.

Pada prinsipnya untuk menentukan wilayah pertambangan (WP) dapat dilakukan hanya dengan metode tumpang tindih lahan (analisis spasial), karena WP merupakan wilayah usaha tambang (WUP, WPR dan WPN) dan secara keruangan belum dinyatakan bahwa wilayah tersebut dapat dilakukan operasional tambang.

Penerapan metode K-means Clustering dilakukan untuk mengelompokkan potensi bahan galian berdasarkan kepada sebagian kecil variabel yang memengaruhi operasional kegiatan penambangan. Dari pernyataan di atas serta hasil analisis data metode ini mempunyai kecenderungan akan lebih tepat digunakan untuk penentuan wilayah ijin usaha tambang (WIUP), karena hasil analisis sudah menetapkan suatu potensi bahan galian untuk dilakukan kegiatan operasional penambangan. Namun demikian penerapan metode K-means Clustering dapat digunakan untuk menentukan suatu wilayah pertambangan (WP) dengan menggambarkan wilayah potensi bahan galian yang telah diterapkan tersebut yang sudah berdasarkan berbagai pertimbangan.

\section{KESIMPULAN DAN SARAN}

Berdasarkan hasil analisis data maka pengelompokkan zonasi kawasan pertambangan dibagi dalam tiga gugus yaitu Gugus 1, 2, dan 3.

Metoda K-means Clustering dapat digunakan untuk memilah suatu daerah yang berpotensi bahan tambang untuk dijadikan lahan usaha tambang atau lebih jauh dapat dialokasikan untuk suatu Wilayah Pertambangan (WP).

Namun untuk ke tingkat yang lebih jauh masih diperlakukan penambahan variabel yang lebih variatif khususnya yang menyangkut dengan opersasional tambang serta analisis ekonomi terhadap potensi bahan galian tersebut, sehingga nantinya dapat menjadi acuan bagi pemerintah daerah dalam proses investasi di bidang pertambangan.

\section{UCAPAN TERIMA KASIH}

Penulis mengucapkan terima kasih kepada Harry Tetra Antono dan kepada semua pihak yang telah memberikan masukan dalam penulisan makalah ini.

\section{DAFTAR PUSTAKA}

Al Rasyid, H. (1993) Teknik penarikan sampel dan penyusunan skala. Universitas Padjajaran.

Antono, H. T., Suryana, N., Wibowo, N. W. and Sujarwo (2009) 'Penentuan zonasi pertambangan (Studi kasus: kawasan Merapi Kabupaten Magelang)'. Bandung.

Dani, U. (2015) Zonasi kawasan pertambangan mineral bukan logam dan batuan dengan metoda analisis spasial untuk mendukung pengembangan wilayah Kabupaten Kulon Progo- D.I. Yogyakarta. Skripsi (tidak diterbitkan). Universitas Padjadjaran.

Hair, J. F., Tatham, R. L., Anderson, R. E. and Black, W. (1998) Multivariate data analysis. 5th Ed. Prentice Hall.

Hilda, R. (2009) K-means clustering berdasarkan nilai pseudo- $F$ dalam pengelompokan lahan usaha tambang. Skripsi (tidak diterbitkan). Universitas Padjadjaran. 
Lattin, J. M., Carroll, J. D. and Green, P. E. (2003) Analyzing multivariate data. Vol. 1. Thomson Brooks/Cole.

Pemerintah Daerah Kabupaten Lebak Provinsi Banten (2014) Rencana tata ruang wilayah (RTRW) Kabupaten Lebak 2014-2034: Materi teknis. Lebak: Pemerintah Daerah Kabupaten Lebak Provinsi Banten. Diakses dari: http://perpustakaan.bappenas.go.id/lontar/file? file $=$ digital/164614-[_Konten_]-Konten D1507.pdf.

Pitney Bowes Software Inc. (2006) Maplnfo Professional: User's guide version 8.5. Pitney Bowes Software Inc.

Suryana, N. (2011) 'Penggunaan metode statistik KMeans clustering pada analisis peruntukan lahan usaha tambang berbasis sistem informasi geografi', Jurnal Teknologi Mineral dan Batubara, 7(1), pp. 42-53. Diakses dari: https://jurnal.tekmira.esdm.go.id/index.php/m inerba/article/view/842.

Suryana, N., Antono, H. T., Wibowo, N. W. and Sujarwo (2005) 'Penyusunan rencana induk kegiatan (RIK) zonasi kawasan pertambangan untuk kebijakan alokasi lahan usaha tambang di daerah Kabupaten Cirebon, Provinsi Jawa Barat', Jurnal Teknologi Mineral dan Batubara, (33), pp. 10-24.

Tim Asistensi Perencanaan Terpadu dan Terkendali (1987) Pengembangan wilayah sektor pertambangan. Jakarta: Departemen Pertambangan dan Energi.

Tunggal, H. S. (2012) Kumpulan peraturan perundang-undangan pertambangan mineral dan batubara. Jakarta: Harvarindo. 
